\title{
International Trade Fairs and Global Buzz, Part I: Ecology of Global Buzz
}

\author{
Harald Bathelt \& Nina Schuldt
}

\begin{abstract}
Version Post-print/accepted manuscript
Citation Bathelt, H., \& Schuldt, N. (2010). International trade fairs and global (published version) buzz, part I: ecology of global buzz. European Planning Studies, 18(12), 1957-1974.
\end{abstract}

Copyright / License

Publisher's Statement This is an Accepted Manuscript of an article published by Taylor \& Francis in European Planning Studies on Dec 2010, available online: http://www.tandfonline.com/10.1080/09654313.2010.515815

Always cite the published version, so the author(s) will receive recognition through services that track citation counts, e.g. Scopus. If you need to cite the page number of the TSpace version (original manuscript or accepted manuscript) because you cannot access the published version, then cite the TSpace version in addition to the published version using the permanent URI (handle) found on the record page. 


\title{
International trade fairs and global buzz, Part I: ecology of global buzz
}

\author{
Harald Bathelt \\ University of Toronto, Department of Political Science, \\ and Department of Geography \& Program in Planning, \\ Sidney Smith Hall, 100 St. George Street, Toronto ON M5S 3G3, Canada, \\ E-mail: harald.bathelt@utoronto.ca, URL: http://www.harald-bathelt.com \\ and \\ Nina Schuldt \\ Faculty of Geography, University of Marburg, \\ Deutschhausstraße 10, D-35032 Marburg, Germany, \\ E-mail:nina.schuldt@web.de
}

Paper submitted to European Planning Studies

* In memoriam Waltraud Bathelt 


\title{
International trade fairs and global buzz, Part I: ecology of global buzz
}

\begin{abstract}
This paper investigates the importance of temporary face-to-face contact and the physical co-presence of global communities in establishing a particular information and communication ecology during international trade fairs, referred to as "global buzz". International trade fairs bring together agents from all over the world and create temporary spaces for presentation and interaction. Within a specific institutional setting, participants not only acquire knowledge through face-to-face communication with other agents, they also obtain information by observing and systematically monitoring other participants. The fact that firms do not necessarily have to be in direct contact with a specific source of information to get access to this knowledge makes participation in these events extremely valuable. International trade fairs have become important expressions of new geographies of circulation through which knowledge is created and exchanged at a distance. This paper analyses the constituting components of global buzz, and aims to dismantle the complexity of this phenomenon in a multi-dimensional way. When applying this concept to Internet trade fairs, the question arises whether a similar information and communication ecology, or virtual buzz, can be established. We explore similarities and differences between both forms of buzz, using the same classification scheme.
\end{abstract}

Keywords. Face-to-face contact, knowledge creation and dissemination, global buzz, international trade fairs, virtual buzz, Internet trade fairs

JEL Classifications. D83, F59, M39, O33, Z13 


\section{Introduction}

In recent work, economic geographers have emphasized the importance of temporary faceto-face (F2F) contact in processes of knowledge creation and dissemination (e.g. Amin and Cohendet 1999; Maskell and Malmberg 1999; Grabher 2002; Norcliffe and Rendace 2003; Maskell, Bathelt and Malmberg 2004; Storper and Venables 2004). Despite the increasing integration of economic networks in global circuits, and the importance of information and communication technologies in everyday business routines, personal contact between people continues to be a decisive mechanism of communicating news, exchanging knowledge and solving problems. However, in the context of global production configurations or peripheral locations outside the industrial core areas, firms do not easily find adequate partners for transactions close-by. They have no choice but to establish linkages over space providing access to distant markets and technologies developed elsewhere. In this context, temporary face-to-face interaction and physical co-presence, as well as forms of virtual proximity and their ability to substitute for spatial proximity, have been the focus of some research in recent years (e.g. Rheingold 1993; Torre and Rallet 2005; Grabher and Maintz 2006; Rallet and Torre 2009). International trade fairs, which enable physical co-location and personal contact of economic agents, have become important temporary platforms of knowledge exchange and networking by making connections regardless of spatial restrictions (Borghini, Golfetto and Rinallo 2004). Focusing on business-to-business (B2B) fairs, this paper argues that these events produce a rich communication and information ecology within a specific institutional setting, referred to as "global buzz" by Maskell, Bathelt and Malmberg (2004). These professional gatherings combine different knowledge pools from firm representatives, scientists, and practitioners, and provide a microcosm for an industry for a limited time period (Rosson and 
Seringhaus 1995). Similar to the effects of Internet-thinking studios and transnational epistemic communities, international trade fairs are viewed as important expressions of new geographies of circulation through which knowledge can be created and exchanged at a distance (Amin and Cohendet 2004; Thrift 2000). Trade fairs are places of consultation between producers and users, providing a platform for producer-controlled participation in user-driven development processes (Grabher, Ibert and Flohr 2008).

Trade fairs have long been the focus of studies in business administration, investigating the importance of such events as sales and marketing instruments to attract new buyers, establish brands and develop a particular image (e.g. Strothmann 1992; Meffert 1993; Backhaus and Zydorek 1997); but the goals behind the participation in leading international trade fairs are manifold (e.g. Kirchgeorg 2003; Power and Jansson and Power 2008). ${ }^{1}$ Only a few studies have, thus far, focused on the nature of communication and information flows during such events. Recently, conceptual and empirical studies have begun to analyse trade fairs as platforms for processes of knowledge creation and circulation, and as places where learning through interaction and by observation takes place (Prüser 1997; Borghini, Golfetto and Rinallo 2004; Maskell, Bathelt and Malmberg 2006; Rinallo and Golfetto 2006; Entwistle and Rocamora 2006; Skov 2006; Bathelt and Zakrzewski 2007; Bathelt and Schuldt 2008a). This work suggests that leading international trade fairs, as temporary clusters, have become central nodes that connect the global

\footnotetext{
${ }^{1}$ It is interesting to note in this respect that the sales function of trade fairs has seemingly become less important compared to other goals. Borghini, Golfetto and Rinallo (2006) found in their study of 11 European trade fairs in the areas of textile/apparel and wood/furniture that up to $50 \%$ of the visitors could be viewed as atypical (i.e. suppliers, competitors, or firms from other sectors). Of the typical visitors (i.e. traders, wholesalers, importers, or industrial customers), on average only $22 \%$ and $34 \%$ actually made purchases at trade-related and industrial fairs, respectively.
} 
political economy, and provide participating firms with access to new technologies, market trends and potential business partners.

Related to the questions how and where firms obtain access to new knowledge and artefacts and to other agents who have generated or adopted these innovations, the main goal of our paper is to dismantle this complex phenomenon, and to show why international trade fairs are decisive events to accommodate such information and knowledge flows. We do this by analysing the complex information and communication ecology in terms of five interrelated components providing a multidimensional conceptualisation. Through this, this paper aims to contribute to a better understanding of opportunities and limitations of temporally and spatially concentrated learning processes between economic agents. The multidimensional classification scheme applied is conceptual in character. It has been developed in a deductive pattern, while being modified and confirmed through extensive empirical studies in an inductive way. ${ }^{2}$ Given the technological advances associated with Internet applications and computer-mediated communication (CMC), one might ask whether virtual spaces of communication can create a similar information and communication ecology, or "virtual buzz". In investigating Internet trade fairs, we come to realise, of course, that this is not a question of substitution as both media of

${ }^{2}$ Our arguments draw from other empirical studies of international trade fairs (e.g. Borghini, Golfetto and Rinallo 2004; Rinallo and Golfetto 2006; Entwistle and Rocamora 2006), as well as our own empirical work conducted between 2004 and 2006 at seven national/international trade fairs in Frankfurt/Main, Nürnberg and Hannover, Germany (see, also, Bathelt and Schuldt 2008a; Schuldt and Bathelt 2008). 
communication co-exist. ${ }^{3}$ Thus, we further aim to discuss the ways in which virtual and global buzz differ from one another and how they can complement one another.

This paper is structured as follows: Section 2 explores the phenomenon of global buzz at international trade fairs and lays out its multidimensional nature. Section 3 conceptualises the complex communication and information ecology during international trade fairs as a set of partly overlapping, interdependent components. Section 4 suggests that aspects of this buzz can also be transmitted through the virtual spaces of Internet fairs, and briefly discusses the similarities and dissimilarities between virtual and global buzz. Section 5 summarises the main findings and discusses the need for further research.

\section{International trade fairs and the phenomenon of global buzz}

International trade fairs are characterised by specific communication and information patterns that develop between the exhibitors, visitors, experts, and observers who get together in these temporary clusters (Maskell, Bathelt and Malmberg 2004). We refer to this professional information and communication ecology as "global buzz". This section describes the phenomenon of global buzz, before analysing the constitutive components which help us to understand the characteristics of this phenomenon, and distinguish between different kinds of buzz (e.g. Borghini, Golfetto and Rinallo 2004; Schuldt and Bathelt 2008). This unique information and communication ecology results from the physical co-presence of a multitude of agents of an industry, technology, or value chain originating from basically all parts of the world.

\footnotetext{
${ }^{3}$ In fact, evidence can be found that shows that virtual occupational communities are connected to trade
} fairs and shape the purchasing behaviour of agents by spreading knowledge and evaluations about products and firms (Rinallo, Golfetto and Borghini 2008). 
At these events, participants discuss and present new developments, and exchange information and knowledge about products, markets, firms, and leading individuals in their area of expertise. The co-location of many agents does not only open up a vast range of possibilities for face-toface interaction, it also enables participants to observe and experience new products, technologies, and designs. Recent research has shown that this buzz consists of news, strategic information, experience, rumours, recommendations, and speculations about an industry or technology branch, all of which are exchanged in an extremely concentrated form over a limited time period of usually three to five days (e.g. Entwistle and Rocamora 2006; Skov 2006). Global buzz is associated with ongoing search processes and depends on reciprocal communication patterns between producers, users, suppliers, and other experts of an industry (Bathelt and Schuldt 2008b; Borghini, Golfetto and Rinallo 2006). ${ }^{4}$ During trade fairs, information flows travel back and forth through various channels, and provide multiple feedbacks to the participating agents. Through this, global buzz generates a multitude of opportunities for learning processes both during and after the trade fairs, and supports the generation and maintenance of business networks over large distances (Prüser 2003; Borghini, Golfetto and Rinallo 2004; Maskell, Bathelt and Malmberg 2006; Power and Jansson and Power-2008).

Of course, global buzz is not the same at each international trade fair, and in each industry, or value chain. It unfolds in different practices and varies according to the purposes and business contexts of the fairs (Bathelt and Zakrzewski 2007). Depending on the perspective used and the

\footnotetext{
${ }^{4}$ We are aware that the term "buzz" is used in different ways in everyday language, often referred to as chatting, gossip, or rumour. In using this term as a metaphor, our aim is to enable potential readers to quickly grasp the concept. However, what we refer to is the specific information and communication ecology in temporary clusters, and not general talk about everyday events.
} 
context analysed, different characteristics structure the practices of global buzz (see, Schuldt and Bathelt 2008).

Although our paper exclusively focuses on the communication and information ecology during international trade fairs, we are aware that similar or related forms of global buzz exist (Bathelt and Schuldt 2008a), associated with, for instance, global business traveling (e.g. Wickham and Vecchi 2008) or transnational epistemic communities (e.g. Portes 2002). As opposed to this kind of buzz, which is characterised by temporary co-presence and face-to-face interaction between people from different parts of the world, interaction through Internet-based communities (e.g. Grabher and Maintz 2006) does not involve physical co-presence. In an extreme situation, global buzz may become a permanent phenomenon of a place, if, as in the case of New York City's women's wear industry (Uzzi 1996; Rantisi 2002), this place continuously attracts talent from an industry and develops into a global multicultural hub of diverse knowledge pools. In this extreme form, temporary global buzz may converge with permanent local buzz (Bathelt, Malmberg and Maskell 2004). ${ }^{5}$

\section{Constitutive components of global buzz}

From the above discussion, it becomes clear that global buzz is a complex phenomenon that is difficult to measure. It cannot be easily condensed into a single variable, and its practices are heterogeneous. In the following, we argue that face-to-face contact is a particularly effective way of acquiring and circulating knowledge because it involves direct interaction and immediate

\footnotetext{
${ }^{5}$ This, of course, does not imply that other places are not also connected to extra-regional knowledge pools. It suggests that we should not interpret "local" and "global", or "permanent" and "temporary", as fixed, separate, or unrelated concepts, but rather focus on their dynamics and interrelations.
} 
feedback (Ibert 2007). In this conceptualisation (Maskell, Bathelt and Malmberg 2004; Bathelt and Schuldt 2008a), global buzz does not just refer to a specific method of communication, such as an informal, group-based, self-generating exchange of information and knowledge outside the context of formal collaborations (e.g. Asheim, Coenen and Vang 2007; Moodysson 2008); it goes much beyond in referring to the entire information and communication ecology. In the context of this paper, global buzz denotes an all-embracing, yet specific constellation of different components generating a professional information and communication ecology. These components are related to global co-presence, intensive face-to-face interaction, different possibilities for observation, intersecting interpretative communities with overlapping visions, as well as multiplex meetings and relationships, all of which occur simultaneously and provide a variety of business opportunities for the participants at international trade fairs (Table 1). We argue that a systematic analysis of these constitutive elements enables a better understanding of the unique characteristics of global buzz and its benefits.

Insert Table 1 about here

The concept of global buzz presented in this paper also does not confuse aspects of copresence, face-to-face contact, information transfer, community formation, and institution building. Rather, it aims to emphasize how different components of information and communication processes during international trade fairs support one another in mutually reflexive ways. For the purpose of clarity, we try to separate these components in the discussion below, while being aware that they are closely related to one another. Dedicated co-presence, for 
instance, is a pre-condition for, as well as a consequence of, both face-to-face interaction and observation practices. Ultimately, we are interested in the ways in which global buzz impacts information and knowledge flows between firms. Since this is based on communication between individuals, our argument focuses on both person-to-person communication and the ways how this communication shapes interaction and competitiveness at the corporate level.

\subsection{Global co-presence}

Dedicated co-presence at and around the fair grounds is a necessary precondition for global buzz. This context establishes a spatial constellation through which specific ensembles of agents meet and interact both in sequence and simultaneously. International flagship fairs are events that bring together leading and less well-known agents from an industry or technological field. Suppliers, producers, users, retailers, interested experts, media representatives, and other multipliers get together to exchange news about the present and future development of their industry, centered around the displays of existing products, prototypes, and innovations. The colocation of many specialised firms from a particular value chain, combined with constant face-toface communication between specialists from these firms, generates a unique milieu for the exchange of state-of-the-art knowledge and experience (Entwistle and Rocamora 2006). Studies indicate that the exchange within this field is more intense and diversified than that which could be expected in an everyday work situation (Bathelt and Schuldt 2008a). From the view of an exhibitor, this exchange might include discussions about business transactions with customers and suppliers, general conversations with interested agents about the character of products and the development of the industry, specific possibilities for problem-solving or improvements, and negotiations with long-term customers from different parts of the world (Borghini, Golfetto and Rinallo 2004). 
Although agents attend trade fairs with different expectations and in different roles, they share a strong dedication to focusing on the activities that take place on the fair grounds for several days in a row (Blythe 2002; Bathelt and Zakrzewski 2007). To be away from the normal workplace creates time slots that are normally not blocked with particular tasks. These time slots allow for unique communication without interruptions, which would be impossible in day-to-day work. Of course, the degree to which the schedules of firm representatives are filled with appointments during such events, and how much time the people can devote to the observation of other exhibits or unplanned meetings, directly depends on their functions and positions (Ausstellungs- und Messeausschuss der deutschen Wirtschaft 2003). While executives and leading managers often have dense schedules with many organised meetings during the fair days, other specialists in research, sales, or planning are more flexible in terms of time (e.g. Prüser 1997).

Because of the specific atmosphere of these "get-togethers", the exclusive focus on exploring an industry's state of the art, and not having to deal with routine administrative issues, people are often more relaxed and open than in regular work situations, yet also highly concentrated. They tend to be open to new ideas, and are willing to critically compare their own industrial practices with those of others (see Borghini, Golfetto and Rinallo 2006). This is conducive to the adaptation of different experiences, and to processes of learning and knowledge dissemination (Schuldt and Bathelt 2008). Especially representatives of small firms emphasize that they use their presence at trade fairs to collect ideas for new products, and acquire an overview of global market needs and players (see Rosson and Seringhaus 1995). They try to identify new trends that could be implemented in their production. Foreign firms often use their presence to prepare market entry in other regions or nations (e.g. Prüser 1997). Firms from less developed countries particularly aim to pick up ideas for designs which they can imitate or adapt 
to the needs of their home markets (Bathelt and Zakrzewski 2007). Media representatives and other multipliers, such as specialised user groups who are not usually in direct contact with producers, also play an important role (e.g. Rinallo and Golfetto 2006; Entwistle and Rocamora 2006; Skov 2006). These agents have a substantial impact on the success of trade fairs and the wider image of the exhibitors, because they serve to mediate their impressions and evaluations to a larger audience of potential buyers and users after the events.

\subsection{Intensive face-to-face interaction}

Another constitutive component of global buzz is its reliance on face-to-face contact. As opposed to other means, modes, and conditions of communication, attendance at international trade fairs automatically involves face-to-face contact with a multitude of agents of a particular industry, through which a diverse mix of information and knowledge can be sorted, classified, and interpreted. It is, of course, well-known that face-to-face communication provides important opportunities for economic agents to disseminate knowledge and stimulate learning. Storper and Venables (2004), for instance, have pointed out the importance of face-to-face interaction in transferring complex messages, getting immediate feedback, and responding further.

Face-to-face communication can reduce information asymmetries, as there are many ways of inquiring about the reliability of new information and the trustworthiness of other agents. Firm representatives grasp additional important inputs when talking to their peers, and by observing their facial expressions and gestures. This is a great aid when making judgements and sorting information (Maskell, Bathelt and Malmberg 2006; Bathelt and Schuldt 2008b). Overall, it helps to identify the mindsets and opinions of other agents, check their compatibility for future business relations, and reduce risks in interaction (Prüser 2007). This indicates that face-to-face communication reflects the nature of social relations between the agents and, by means of 
feedback and interpretation, serves to further shape existing relationships (Watzlawick, Beavin and Jackson 2000; Gallié and Guichard 2002).

But agents not only acquire knowledge when participating in face-to-face communication with others, information is also absorbed by observing and systematically monitoring the exhibitors and visitors. By "being there" and experiencing the exhibits, agents can grasp the symbolic character and emotional value of new products or designs (Schlink 2006). ${ }^{6}$ The unique combination of developing, discussing and exchanging arguments with others can readily be applied to one's own production or product range, while, at the same time, being able to observe the effects on other agents. This provides instant insights that would be extremely difficult to acquire through other means (Sharland and Balogh 1996; Blythe 2002).

It is also interesting to note that firms do not necessarily have to be in direct contact with a specific source of information to have access to that information. Participants might hear from other agents about new developments and decide themselves whether or not it would be useful to inspect these innovations personally. Through this, agents greatly benefit from the decentralised character of information flows and the multiplicity of channels that exist during trade fairs. ${ }^{7}$

${ }^{6}$ We are aware that different types of knowledge can be differentiated (e.g. Asheim and Gertler 2005). In our context, which focuses on in-situ practices of interaction and knowledge circulation, we do not need to draw on such distinctions.

${ }^{7}$ Of course, there are also examples of how critical evaluations in media reports can negatively impact a firm's commercial success. Furthermore, buzz can have negative effects, especially if consciously used to spread false information about products, markets, and other agents. It could harm the reputation of third parties, and lead a firm to focus on less prospective developments. However, since participants in trade fairs are in contact with a multitude of different agents, it is unlikely that misleading information spread by one party would have a substantial impact. Normally, individuals are constantly confronted with similar types of information during a trade fair, and 
Of course, we do not suggest that the effects of face-to-face contact are the same irrespective of the character of a trade fair and the products, technologies, or fashion trends shown (see, also, Fuchs 2003). In fact, ongoing research shows that substantial differences exist (Schuldt and Bathelt 2008). First, in design-intensive industries the symbolic and emotional value of exhibits might be particularly important requiring face-to-face contact to acquire knowledge, which is largely tacit and contextual (Asheim and Gertler 2005). Agents quickly get a first impression of, and a feeling for, new products which are shown. Second, in investment goods fairs, interest in the actual exhibits might be limited as it is difficult to evaluate technical properties. In this context, personal meetings appear to be more important to maintain positive business contacts through face-to-face communication with customers and suppliers from other parts of the world (Backhaus 1992; Rosson and Seringhaus 1995; Sharland and Balogh 1996; Meffert 2003).

\subsection{Manifold possibilities for dense observation}

Firm representatives attending trade fairs do not just gain access to new information and knowledge through face-to-face communication; important insights also result from observing the exhibits, both systematically and sporadically, as well as the exhibitors and visitors. Through practices, such as close inspection of other exhibits, peer observation, "being part of the crowd", and watching the reaction of other visitors, agents collect ideas and impressions that are used to revise or confirm existing strategies regarding the production program (e.g. Blythe 2002; Meffert 2003; Bathelt and Schuldt 2008a; Schuldt and Bathelt 2008). International trade fairs are events 
that also attract leading, "unusual", and "exotic" agents from an industry or technology branch, providing plenty of opportunities for learning-by-observation or learning-by-inspection (Borghini, Golfetto and Rinallo 2006).

When considering structural and substantive characteristics of communication at trade fairs, small start-up firms with little market experience and firms from less developed regions or countries often present their products in joint exhibits, while innovative firms present their latest design ideas in large elaborate booths, sometimes set up as stages. Each firm clearly aims to attain market access with its products, discover new markets niches, or get an idea about market developments. Due to the diversity of agents, the products displayed cover a vast range of different materials, designs, and technology paths, from cheap supplies to lean environmentally friendly solutions or highly exclusive accessories. What is important for the process of acquiring information is to experience this microcosm of an industry's products and problem solutions (Rosson and Seringhaus 1995; Backhaus and Zydorek 1997; Fuchslocher and Hochheimer 2000).

While examining the exhibits of competing or complementary firms, agents are also able to evaluate the goals of trade fair participation of others (Borghini, Golfetto and Rinallo 2004). This could be in line with the expectations one might have of a competitor, or it might deviate from these, indicating that that firm has begun to operate in a different market context. The latter might be a trigger to scan the firm more closely during and after the trade fair. Similar to gestures and facial expressions in face-to-face communication, the observation and experience of a competitor's trade fair exhibit can be viewed as a visualisation of this firm's broader philosophy (Bathelt and Schuldt 2008a). Among the inspection of other exhibits for aspects of uniqueness, creativity, and design, exhibitors also take notice of the frequency of visitors and their reactions at their own booth, or that of others. 
Overall, this suggests that systematic and open-minded observation enables firms to become aware of important trends, and confirm or revise knowledge regarding markets and technologies. This may leave observers with a feeling of security or of "being in-the-know". In other cases, agents may become aware that they should explore new paths, or that they need to readjust their strategies. In short, ongoing search processes during trade fairs can lead to unexpected knowledge, inspiration, and reassurance (Borghini, Golfetto and Rinallo 2006). In any case, the observation and scanning of other firms and their exhibits in a spatially concentrated form clearly becomes a core component of global buzz.

\subsection{Intersecting focused communities, shared understandings and overlapping visions}

Another component of global buzz relates to the communities that meet during international trade fairs, the visions they share or create, and, more generally, their institutional basis. Such focused events clearly attract different, yet closely interrelated communities which have in-depth knowledge surrounding many aspects of the products, technologies, and value chain portrayed (e.g. Skov 2006; Entwistle and Rocamora 2006). The participants are experienced in producing, using and/or selling products and technologies, and, through this, share a common language and expertise. In general, we can expect that both communities of practice (Brown and Duguid 1991; Wenger 1998) and epistemic communities (Knorr Cetina 1999) meet during international fairs, turning them into large conglomerates of similar or shared understandings, repertoires, and visions about an industry or technological field.

First, communities of practice derive from day-to-day interaction and regular meetings. Empirical studies have shown that conventional or mutual trust may develop in this interaction as members continue to tell stories about their work to bridge the gap between theoretical and practical knowledge (Brown and Duguid 2000). This trust appears to enter a trade fair and 
stimulate communication patterns which are more open than in an everyday situation (Bathelt and Schuldt 2008a). Shared experience in solving the same sort of problems and/or similar expectations or qualifications support the development of mutual engagement, shared repertoire, and negotiation of meaning (Wenger 1998). Communities of practice can develop within a firm but it has been suggested that they may also extend beyond a single organisation to include other firms in a value chain (e.g. Gertler 2001). These communities provide a valuable source of knowledge that cuts across the strict boundaries of corporate structures (Lawrence, Payne and De Roure 2006). In our view, this may also encompass trade fairs. Overall, we assume that international trade fairs are important events where such communities meet regularly or periodically.

Second, epistemic communities are generally based on a similar specialisation and learning experience, for instance acquired during their formal training. This supports the development of shared technological views, and the use of the same vocabulary. Members of epistemic communities, which can be quite widespread even across sectors, share some swift trust related to the norms and goals acquired through their training (e.g. Knorr Cetina 1999). It is important to note that these communities share a similar institutional basis, enabling them to efficiently exchange and interpret knowledge, generate new ideas, and develop competencies further in a collective manner. Evidence suggests that different partially related epistemic communities get together at leading trade fairs (e.g. Entwistle and Rocamora 2006).

We anticipate that these establish "focused communities" which play an important role in problem solving, strategy development, the diffusion of best-practice technologies, and in interpreting important trends. By no means, however, do the participants of trade fairs share the same identical background, or are all part of the same community (Schuldt and Bathelt 2008). Some participants who are experienced in production are, for instance, interested in discussing 
problems of product quality, design, or technical failure, while others, such as sales specialists, mainly interact with customers and are eager to get to know more about demand changes and new trends. In sum, we encounter firms that are specialised in different segments of the value chain (Rosson and Seringhaus 1995). Therefore, experts with somewhat different expertise and technological focus gather during international trade fairs, meeting their respective groups of peers with whom they share impressions, perceptions, and expectations (Prüser 2003; Borghini, Golfetto and Rinallo 2006). In addition, various groups of users and observers, who do not have direct contact with producers or the creatives in their day-to-day routines, attend trade fairs. Depending upon the type of information and knowledge, which might substantially differ between creative and technology-based industries, global buzz can occur in different forms depending on the industry or firm context (e.g. Prüser 1997; Kirchgeorg 2003; Schuldt and Bathelt 2008). Regardless of its specific form, we argue that this buzz is a key ingredient of the trade fair experience and the attractiveness of these events.

The decisive point of the above argument is that the visitors and exhibitors at international trade fairs are characterised by some degree of common knowledge basis, or cognitive proximity (Nooteboom 2000). Despite differences, the knowledge basis of many agents is likely sufficiently close to that of others, allowing for efficient transfers of information and knowledge. It also serves to stimulate joint interpretations of new information and extract those knowledge components that could be valuable in future applications. In addition, the existence of some degree of heterogeneity is important because it increases the chances that firms might discover 
something that is novel to them. ${ }^{8}$ Due to this unique mix of similar, overlapping, and complementary knowledge, important learning processes are stimulated at international trade fairs (Borghini, Golfetto and Rinallo 2006; Bathelt and Zakrzewski 2007).

Overall, active participation in focused communities reduces uncertainties and the degree of complexity when making decisions regarding technological shifts. Through this, it can be anticipated that new knowledge and technologies can be easily circulated and understood. This mechanism enables agents at trade fairs to distinguish more valuable from less valuable knowledge, and to sort through innovations of others that could be worth exploring further.

\subsection{Multiplex meetings and relationships}

The multitude of relationships and personal contacts that develop during international trade fairs stimulate tight networks of information and knowledge flows. Analyses of the structural characteristics of communication indicate that business partners, colleagues, peers, or community members can meet at different places and in different ways - for example, in scheduled or accidental meetings, in a hallway, café, or hotel lobby (Bathelt and Schuldt 2008a). We argue that this diversity of possibilities is necessary for the creation and dissemination of global buzz. Moreover, international trade fairs have become complex societal events which include leisure activities such as presentations of avant garde foods, arts performances, as well as after-fair evening events with a multicultural flavour (Blythe 2002; Prüser 2003). This is not always

\footnotetext{
${ }^{8}$ We have to keep in mind that basic technical standards are not homogenised at a global scale. Due to
} deviating national/international standards, different knowledge practices exist which involve different traditions and skill sets. Trade fairs are an ideal place where aspects of technology transfer and harmonisation can be discussed and negotiated between specialised communities. This is also exemplified by a large number of seminars and specialtygroup meetings which are organised during these events. 
directly related to the technology or industry focus but provides opportunities to get to know people in an informal way and in different roles. While there is usually not much time to attend such events, these are often welcome interruptions from daily work routines. ${ }^{9}$ This can be inspiring and open up conversations, be it with existing or new contacts, or random acquaintances.

Within these networks of contacts, agents are linked in different ways with each other as business partners, colleagues, peers, or community members. As a result, resources can likely be transferred from one type of relationship to another. Multiplex ties and the diverse possibilities for meetings at international trade fairs help agents to gain access to new information, accelerate the transfer of knowledge, and increase the firms' access to relevant knowledge pools (Boissevain 1974; Uzzi 1997). During a fair, information is constantly transmitted from one agent to another. This process is repeatedly interpreted, evaluated, and enriched with additional relevant information and knowledge (Schuldt and Bathelt 2008). The decisive point is that while acquiring new knowledge, participants act simultaneously as both recipients and broadcasters of global buzz (see, also, Goffman 1969). The potential advantages and benefits of applying this knowledge become clearer as the trade fair evolves and interpretations are drawn from the variety of meetings.

When decision-makers and technical specialists, for instance, meet with peers for dinners, they also discuss issues related to each other's private life. While there is no doubt that most of these relationships are primarily geared towards business issues, trade fairs are much more than just arenas for professional talk and serious conversations. Similar to the discussion by Massey

${ }^{9}$ Not all participants, however, might enjoy these work interruptions in the same way. Executives, who participate in many trade fairs every year, and attend these events for one or two days only, might find the performative character of these events quite disruptive. 
(2004), these events involve feelings and emotions, and participants generally expect to be "having a good time". While the development of conventional trust between business partners may take a long time, the existence of swift trust and repeated meetings during international trade fairs establish a favourable basis for the stimulation of new business relations. ${ }^{10}$

Often discussions do not stop at the end of the normal trade fair day but are continued through the evening over dinner and drinks. Sometimes, this involves important customers and helps strengthen existing relationships. At other times, this can be the first step in the establishment of a new partnership. Firms that aim to enter new markets and search for partners to support this move particularly benefit from such meetings, which are often spontaneous and not planned long in advance (Prüser 2003; Maskell, Bathelt and Malmberg 2004). These encounters also help check out the "chemistry" between two parties, establish some initial communication, or are simply reason enough to rule out further communication. In sum, trade fairs enable participants to constantly switch from negotiations to observations, from straight business talks to private conversations after a few beers, and back - and all of this within a single day or two. In this sense, trade fairs provide unique opportunities for truly multiplex encounters at an international scale.

${ }^{10}$ One has to keep in mind that the process of establishing business relationships is not related to a singular trade fair (e.g. Godar and O'Connor 2001; Power and Jansson and Power-2008). Firms often participate in half a dozen or more such events per year. Their annual work routines are often structured according to these trade fairs. Processes of community building could benefit from this as similar groups of actors may come together and communicate repeatedly. 


\section{Virtual buzz in Internet trade fairs}

In the above conceptualisation, global buzz refers to the specific information and communication ecology which develops in the temporary settings of international trade fairs. Such events support the diffusion of information and knowledge over large distances between different places, regions, and nations around the globe, thus building real-time bridges across physical space (e.g. Walther, Loh and Granka 2005; Rothe 2006; Moriset and Malecki 2008). One question that arises is why these events, which rely on physical co-presence, are still so unique, or why they have not been substituted by virtual trade fairs, which became popular in the mid 1990s (Moellenberg and Teichmann 2000; Chizzoli 2003). Observers might expect, for instance, that conventional forms of face-to-face communication and observation are increasingly substituted by Internet trade fairs. Cyber space may appear as the ultimate frontier of space-time compression (Harvey 1990; Dicken 2003). At the same time, it is obvious that personal contact, even in business relations, cannot always easily be substituted (Torre and Rallet 2005; Wickham and Vecchi 2008; Rallet and Torre 2009).

Table 1 summarises characteristics of both forms of buzz in a systematic way. This is based on explorative interviews conducted at international trade fairs, inspections of virtual tradefair sites, and a literature review of virtual trade fairs (i.e. Backhaus and Zydorek 1997; Fuchslocher and Hochheimer 2000; Heintz 2000; Moellenberg and Teichmann 2000; DeeterSchmelz and Kennedy 2002; Goehrmann 2003; Chizzoli 2003). Overall, there is still a lack of broad systematic empirical studies on virtual trade fairs. In what follows, we briefly compare the constituting components of global and virtual buzz, using the same classification scheme as above. This comparison aims to highlight the main similarities and differences in information flows and communication between real-world and cyber-space fairs. 
First, co-presence as "a form of human co-location in which individuals become accessible, available, and subject to one another" (Goffman 1969, p. 22) stimulates important information and knowledge transfers between individuals. In this respect, web applications related to virtual fairs involve an element of universal presence because the information provided by firms can be stored and made available to potential users at any point in time. Co-presence in the sense of Goffman (1969) is, however, only partially being created through platforms that connect the participants in real time (von Hippel 2001; Zhao 2003; Ayaß 2005; Lawrence, Payne and De Roure 2006).

Second, another aspect that distinguishes conventional trade fairs from Internet fairs is that the participants of the latter events are unlikely to share the same degree of dedication, patience, and openness to new ideas. As virtual observation occurs in the context of their work places, attention can easily be distracted by issues that come up during their regular work routines (Backhaus and Zydorek 1997; Deeter-Schmelz and Kennedy 2002).

Third, the combination of face-to-face contact and observation during trade fairs serves as a direct feedback mechanism. This constitutes a dense milieu of global buzz and stimulates additional buzz. In virtual fairs, the milieu is less dense as fewer agents scan exhibits and exchange information at the same time (Grimm 2004). It also appears that the mixture of agents in virtual fairs is sometimes not as specific, and that relevant peers are more difficult to identify compared to a physical trade fair. This is supported by the fact that many events that were initiated during the 1990s have been unsuccessful, and do not exist any longer. ${ }^{11}$

${ }^{11}$ This is confirmed by a study of Chizzoli (2003) on the performance of eMarketplaces at an international level. Using a broader definition of B2B electronic events, Chizzoli (2003) found for the time period from 1998 to 2002 that $25-35 \%$ of all electronic markets failed, and consequently disappeared. 
Fourth, sensible relations and imaginations are bound to direct interpersonal contact ("touch and feel") and cannot be easily compensated for through technical media. Further, firms handle the transfer of specific information and knowledge in virtual communication very carefully. This is especially the case if the exact identity of the counterparts is not known, and if the true intentions of other agents are unclear. In such contexts, it would be difficult to acquire information as cost-efficiently as through global buzz at trade fairs, or to readily develop initial trust (Borghini, Golfetto and Rinallo 2004).

Fifth, if it is possible to address the respective group of specialists in an industry and attract them to participate in a professional Internet fair, there is no reason to assume that an exchange of valuable knowledge and experience would be unlikely or impossible (see, also, Goehrmann 2003). Virtual events may sometimes be an attractive alternative to personal meetings if a quick response or feedback is needed, or if it is too complicated to organise a face-to-face meeting (Hildreth 2004). Especially, agents in relatively isolated locations, or in industries with shortterm deadlines, might find participation in Internet fairs particularly valuable. Important differences to physical fairs are a lesser degree of dedication, stronger goal-orientation, and the absence of face-to-face contacts between and within exhibitor and user groups.

\section{Conclusions: buzz in physical and virtual context}

This paper argues that global buzz at leading international trade fairs enables firms to systematically acquire information and gain new knowledge about competitors, suppliers, customers, and their technological and strategic choices - through many different routes and in a nearly simultaneous fashion. Through this, global buzz serves to create reference points for firms regarding their activities and strategies in an industry or technology branch. The argument developed in this paper is that a specific communication and information ecology, referred to as 
global buzz, exists, which enables unique processes of knowledge dissemination and creation through interactive learning and learning by observation. We describe global buzz as a phenomenon that can be found at international trade fairs - among other forms of global interaction. It can be conceptualised in a multi-dimensional way by a specific architecture of different components. On the one hand, it can be systematically analysed according to these components. On the other hand, global buzz is highly contextual and thus necessarily involves varying communication practices. This conceptualisation helps to explore this phenomenon more thoroughly, and enables a better understanding of different kinds of buzz and their potential benefits. Our analysis suggests that face-to-face interaction is an extremely efficient form of communicating buzz (see, also, Zhao 2003), although it is, by no means, a necessary requirement to enable global information and knowledge exchange.

Using this conceptualisation, we pose the question whether global buzz can be substituted by virtual buzz related to Internet fairs. Our enquiry indicates that similar forms of virtual buzz may exist in digital business worlds (see, also, Walther, Loh and Granka 2005). This virtual buzz is, however, also different from global buzz due to its structural, substantive, communicationmedia, and functional characteristics. This is related to the fact that Internet-based events are associated with different references and motivations compared to real-world fairs. We should, however, not expect that there is competition between both forms of trade fairs. Depending on the communication needs and the products exhibited, the potential of digital media to accommodate trade fairs might differ. In general, we can assume that interaction in physical space is richer than interaction in Internet trade fairs, because the latter cannot transfer feelings and mediate associations in the same way as real-world trade fairs. Having said this, virtual buzz can, of course, support technology development and problem solving at a global level through professional Internet platforms, and intra-firm or corporate software networks (see von Hippel 
2001; Jeppesen and Molin 2003; Rinallo, Golfetto and Borghini 2008; Grabher, Ibert and Flohr 2008). Virtual spaces develop parallel to our material reality, shaping and reshaping it continuously.

Due to the wide range of professional coupling opportunities related to the combination of intensive and systematic interaction with unplanned and less dense face-to-face communication, international trade fairs will likely remain important, or become even more significant, focal intersections, or mandatory passage points, of transnationally operating firms that connect agents, resource locations, and markets in the global political economy. It is unlikely that these events will be replaced by virtual meetings in the near future as global buzz needs real places to unfold, especially since only few of these virtual events have been successful.

Overall, we have to emphasize that our empirical knowledge about the role of trade fairs in the knowledge economy is still limited at this point. In this respect, it appears that these events have been underestimated in the broader social science literature for quite some time. There is a need to understand better how leading international trade fairs fit into the firms' portfolios of acquiring information and knowledge about trade fairs, or how learning and search processes of agents operate at these events. In addition, we know relatively little about the processes how knowledge gained at trade fairs enters the firms' strategies and innovation processes, and whether we can identify collective responses, for instance in clusters. Little is also known about the geography of the trade fair business, aside from general regional multiplier effects. This work is, in our view, especially important as real-world and virtual trade fairs might gain in importance in a future world that is characterised by high transportation cost, decreased mobility, and fewer opportunities to get together at a global basis, due to environmental aspects and the effects of "peak oil". 


\section{Acknowledgements}

Parts of this paper were presented in 2007 at the Annual Meeting of the Association of American Geographers in San Francisco and the Second Global Conference on Economic Geography in Beijing, and in 2009 at the Workshop on "Creative Cities" of CRÉ de Montréal and the Department of International Business at HEC Montréal. It draws upon research which was jointly conducted by both authors, who contributed equally to this paper. For critical comments and thoughtful remarks at different stages, we wish to thank Bjorn Asheim, Bill Beyers, Lars Coenen, Patrick Cohendet, Peter Dannenberg, Rachael Gibson, Atle Hauge, Oliver Ibert, Nicole Kogler, Raj Kollmorgen, Kati-Jasmin Kosonen, Roger Lee, Michael Plattner, Allen Scott, and Clare Wiseman. Many of the ideas developed in this paper have also benefited from close collaboration with Anders Malmberg and Peter Maskell (see, Maskell, Bathelt and Malmberg 2004; 2006). Parts of this research were funded by the Social Sciences and Humanities Research Council of Canada, and Weber Maschinenbau GmbH in Breidenbach, Germany.

\section{References}

Amin, A. and Cohendet, P. (1999): Learning and adaptation in decentralized business networks. Environment and Planning A 17: 87-104.

Amin, A. and Cohendet, P. (2004): Architectures of Knowledge: Firms, Capabilities, and Communities. Oxford, New York: Oxford University Press.

Asheim, B., Coenen, L. and Vang, J. (2007): Face-to-face, buzz, and knowledge bases: sociospatial implications for learning, innovation, and innovation policy. Environment and Planning C 25: 655 - 670 .

Asheim, B. T. and Gertler, M. S. (2005): The geography of innovation: regional innovation systems. In: Fagerberg, J., Mowery, D. C. and Nelson, R. R. (Eds): The Oxford Handbook of Innovation. Oxford: Oxford University Press, pp. 291-317. 
Ausstellungs- und Messeausschuss der deutschen Wirtschaft (2003): Informationsverhalten von Fachbesuchern auf Messen. AUMA edition No. 17. Berlin.

Ayaß, T. (2005): Interaktion ohne Gegenüber? (Interaction without counterpart?). In: Jäckel, M. and Mai, M. (Eds.): Online-Vergesellschaftung? Mediensoziologische Perspektiven auf neue Kommunikationstechnologien (Online Socialisation? Sociological Perspectives on New Communication Technologies). Wiesbaden: VS Verlag für Sozialwissenschaften, pp. $33-50$.

Backhaus, H. (1992): Investitionsgütermarketing (Investment Goods Marketing). München: Vahlen.

Backhaus, H. and Zydorek, C. (1997): Von der Mustermesse zur ubiquitären Messe (From sample fairs to ubiquitous trade fairs). In: Meffert, H., Necker, T. and Sihler, H. (Eds.): Märkte im Dialog: Die Messen der dritten Generation (Markets in Dialogue: Trade Fairs of the Third Generation). Wiesbaden: Gabler, pp. 134-158.

Bathelt, H., Malmberg, A. and Maskell, P. (2004): Clusters and knowledge: local buzz, global pipelines and the process of knowledge creation. Progress in Human Geography 28: 3156.

Bathelt, H. and Schuldt, N. (2008a): Between luminaires and meat grinders: international trade fairs as temporary clusters. Regional Studies 42: 853-868.

Bathelt, H. and Schuldt, N. (2008b): Temporary Face-to-Face Contact and the Ecologies of Global and Virtual Buzz. SPACES 2008-04. Toronto, Heidelberg: University of Toronto, University of Heidelberg (Internet: http://www.spaces-online.com, date accessed July 20, 2009).

Bathelt, H. and Zakrzewski, G. (2007): Messeveranstaltungen als fokale Schnittstellen der globalen Ökonomie (Trade fairs as focal intersections in the global economy). Zeitschrift für Wirtschaftsgeographie 51: 14-30.

Blythe, J. (2002): Using trade fairs in key account management. Industrial Marketing Management 31: 627-635.

Boissevain, J. (1974): Friends of Friends: Networks, Manipulators and Coalitions. Oxford: Blackwell.

Borghini, S., Golfetto, F. and Rinallo, D. (2004): Using Anthropological Methods to Study Industrial Marketing and Purchasing: An Exploration of Professional Trade Shows. Paper presented at the Industrial Marketing Purchasing Conference, Copenhagen (URL: 
http://www.europa.eu.int/comm/enterprise/enterprise_policy/spec/documents/fondazione fiera_milano.pdf, date accessed February 14, 2006).

Borghini, S., Golfetto, F. and Rinallo, D. (2006): Ongoing search among industrial buyers. Journal of Business Research 59: 1151-1159.

Brown, J. S. and Duguid, P. (1991): Organizational learning and communities of practice: toward a unified view of working, learning, and innovation. Organization Science 2: 40-57.

Brown, J. S. and Duguid, P. (2000): Balancing act: how to capture knowledge without killing it. Harvard Business Review 78 (May-June): 73-80.

Chizzoli, C. (2003): Technological Versus Market-Based Competences in a Market Created by Innovation: Empirical Evidence from Italian Business-to-Business eMarketplaces. Mimeo. Milan: Business Management and Administration, Bocconi University.

Deeter-Schmelz, D. R. and Kennedy, K. N. (2002): An exploratory study of the Internet as an industrial communication tool. Industrial Marketing Management 31: 145-154.

Dicken, P. (2003): Global Shift: Reshaping the Global Economic Map in the 21st Century. 4th edition, London, Thousand Oaks, CA: Sage.

Entwistle, J. and Rocamora, A. (2006): The field of fashion materialized: a study of London Fashion Week. Sociology 40: 735-751.

Fuchs, W. (2003): Management der Business-to-Business-Kommunikation: InstrumenteMaßnahmen - Beispiele (Management of Business-to-Business Communication: Instruments - Measures - Examples). Wiesbaden: Gabler.

Fuchslocher, H. and Hochheimer, H. (2000): Messen im Wandel: Messemarketing im 21. Jahrhundert (Trade Fair Marketing in the 21st Century). Wiesbaden: Gabler.

Gallié, E.-P. and Guichard, R. (2002): The Impact of ICT Sophistication on Geographically Distant Networks: The Case of Space Physics as seen from France. Presented at the Workshop TIC et réorganisation spatiale des activités économiques, Brest (URL: http://www-eco.enst-bretagne.fr/workshop2002/NTIC-etsante/Communications/Gallie_Guichard.pdf, date accessed May 9, 2007).

Gertler, M. S. (2001): Best practice? Geography, learning and the institutional limits to strong convergence. Journal of Economic Geography 1: 5-26.

Godar, S. H. and O'Connor, P. J. (2001): Same time next year - buyer trade show motives. Industrial Marketing Management 30: 77-86. 
Goehrmann, K. E. (2003): Die Nutzung der IT auf der Messe steht erst am Anfang (The application of IT during trade fairs is only just beginning). WirtschaftsKurier, November, p. 24.

Goffman, E. (1969): Behavior in Public Places. New York: Free Press.

Grabher, G. (2002): Cool projects, boring institutions: temporary collaboration in social context. Regional Studies 36: 205-214.

Grabher, G., Ibert, O. and Flohr, S. (2008): The neglected king: the customer in the new knowledge ecology of innovation. Economic Geography 84: 253-280.

Grabher, G. and Maintz, J. (2006): Learning in Personal Networks: Collaborative Knowledge Production in Virtual Forums. Working Paper Series. New York: Center on Organizational Innovation, Columbia University (URL: http://www.coi.columbia.edu, date accessed July 8, 2007).

Grimm, C. (2004): Möglichkeiten und Grenzen des Beziehungsmarketings im Messewesen (Opportunities and Limitations of Relationship Marketing in the Trade Fair Business). Schriften zum Innovativen Marketing, Band 11. Nürnberg: GIM-Verlag.

Harvey, D. (1990): The Condition of Postmodernity: An Enquiry into the Origins of Cultural Change. Cambridge, MA, Oxford: Blackwell.

Heintz, B. (2000): Gemeinschaft ohne Nähe? Virtuelle Gruppen und reale Netze (Community without proximity? Virtual groups and real networks). In: Thiedeke, U. (Eds.): Virtuelle Gruppen: Charakteristika und Problemdimensionen (Virtual Groups: Characteristics and Problems). Opladen: Westdeutscher Verlag, pp. 188-218.

Hildreth, P. M. (2004): Going Virtual: Distributed Communities of Practice. Hershey, London: Idea Group Publishing.

Ibert, O. (2007): Towards a geography of knowledge creation: the ambivalences between 'knowledge as an object' and 'knowing in practice'. Regional Studies 41: 103-114.

Power, D. and Jansson, J. and Power, D. (2008): Cyclical clusters in global circuits: overlapping spaces and furniture industry trade fairs. Economic Geography 84: 423-448.

Jeppesen, L. B. and Molin, J. M. (2003): Consumers as co-developers: learning and innovation outside the firm. Technology Analysis \& Strategic Management 15: 363-383.

Kirchgeorg, M. (2003): Funktionen und Erscheinungsformen von Messen (Functions and types of trade fairs). In: Kirchgeorg, M., Dornscheidt, W. M., Giese, W. and Stoeck, N. (Eds.): Handbuch Messemanagement: Planung, Durchführung und Kontrolle von Messen, 
Kongressen und Events (Handbook of Trade Fair Management: Planning, Execution and Control of Trade Fairs, Conventions and Events). Wiesbaden: Gabler, pp. 51-72.

Knorr Cetina, K. (1999): Epistemic Cultures: How the Sciences Make Sense. Chicago: Chicago University Press.

Lawrence, J., Payne, T. R. and De Roure, D. (2006): Co-Presence Communities: Using Pervasive Computing to Support Weak Social Networks. Paper presented at the 15th IEEE International Workshops on "Enabling Technologies: Infrastructure for Collaborative Enterprises”, Manchester (URL: http://eprints.ecs.soton.ac.uk/12684/01/DMC2006.pdf, date accessed January 10, 2007).

Maskell, P., Bathelt, H. and Malmberg, A. (2004): Temporary Clusters and Knowledge Creation: The Effects of International Trade Fairs, Conventions and Other Professional Gatherings. SPACES 2004-04. Marburg: University of Marburg (URL: http://www.spaces-online.com, date accessed May 5, 2007).

Maskell, P., Bathelt, H. and Malmberg, A. (2006): Building global knowledge pipelines: the role of temporary clusters. European Planning Studies 14: 997-1013.

Maskell, P. and Malmberg, A. (1999): The competitiveness of firms and regions:

'ubiquitification' and the importance of localized learning. European Urban and Regional Studies 6: 9-25.

Massey, D. (2004): Geographies of responsibility. Geografiska Annaler B 86: 5-18.

Meffert, H. (1993): Messen und Ausstellungen als Marketinginstrument (Trade fairs and exhibitions as marketing tools). In: Goehrmann, K. E. (Ed.): Polit-Marketing auf Messen (Marketing Policy on Trade Fairs). Düsseldorf: Wirtschaft und Finanzen, pp. 74-96.

Meffert, H. (2003): Ziel und Nutzen der Messebeteiligung von ausstellenden Unternehmen und Besuchern (Goals and effects of trade fair participation). In: Kirchgeorg, M., Dornscheidt, W. M., Giese, W. and Stoeck, N. (Eds.): Handbuch Messemanagement: Planung, Durchführung und Kontrolle von Messen, Kongressen und Events (Handbook of Trade Fair Management: Planning, Execution and Control of Trade Fairs, Conventions and Events). Wiesbaden: Gabler, pp. 1145-1163.

Moodysson, J. (2008): Principles and practices of knowledge creation: on the organization of "buzz" and "pipelines" in life science communities. Economic Geography 84: 449-469. Moellenberg, A. and Teichmann, O. (2000): Die virtuelle Messe als Marketinginstrument: Bestandsaufnahme und Zukunftsperspektiven (The Virtual Trade Fairs as a Marketing 
Instrument). Arbeitspapier AP-Nr. 00/04. Braunschweig: University of Braunschweig (URL: http://www.wiwi.tu-bs.de/marketing/publikationen/ap/ap_liste.htm, date accessed June 25, 2008).

Moriset, B. and Malecki, E. J. (2008): Organization vs. Space: The Paradoxical Geographies of the Digital Economy. Paper presented at the Annual Meeting of the Association of American Geographers, Boston.

Nooteboom, B. (2000): Learning and Innovation in Organizations and Economies. Oxford: Oxford University Press.

Norcliffe, G. and Rendace, O. (2003): New geographies of comic book production in North America: the new artisans, distancing, and the periodic social economy. Economic Geography 79: 241-273.

Portes, A. (2002): Transnational entrepreneurs: an alternative form of immigrant economic adaptation. American Sociological Review 67: 278-298.

Prüser, S. (1997): Messemarketing: Ein netzwerkorientierter Ansatz (Trade Fair Marketing: A Network Approach). Wiesbaden: Deutscher Universitäts-Verlag.

Prüser, S. M. (2003): Die Messe als Networking-Plattform (Trade fairs as a platform for networking). In: Kirchgeorg, M., Dornscheidt, W. M., Giese, W. and Stoeck, N. (Eds.): Handbuch Messemanagement: Planung, Durchführung und Kontrolle von Messen, Kongressen und Events (Handbook of Trade Fair Management: Planning, Execution and Control of Trade Fairs, Conventions and Events). Wiesbaden: Gabler, pp. 1181-1195.

Rallet, A. and Torre, A. (2009): Temporary Geographical Proximity for Business and Work Coordination: When, How and Where? SPACES online 2009-02. Toronto, Heidelberg: University of Toronto, University of Heidelberg. (Internet: http://www.spaces-online.com, date accessed August 5, 2009).

Rantisi, N. (2002): The local innovation system as a source of 'variety': openness and adaptability in New York City's Garment District. Regional Studies 36: 587-602.

Rheingold, H. (1993): The Virtual Community: Homesteading on the Electronic Frontier. Reading, MA: Addison-Wesley.

Rinallo, D. and Golfetto, F. (2006): Representing markets: the shaping of fashion trends by French and Italian fabric companies. Industrial Marketing Purchasing-Management 35: 856-869. 
Rinallo, D., Golfetto, F. and Borghini, S. (2004): Building Market Knowledge Together: A Netnographic Study of Online Occupational Communities. Paper presented at the Industrial Marketing Purchasing Conference, Uppsala (URL:

http://www.impgroup.org/uploads/papers/6368.pdf, date accessed October 29, 2009).

Rosson, P. J. and Seringhaus, F. H. R. (1995): Visitor and exhibitor interaction at industrial trade fairs. Journal of Business Research 32: 81-90.

Rothe, F. (2006): Zwischenmenschliche Kommunikation: Eine interdisziplinäre Grundlegung (Inter-personal Communication: An Interdisciplinary Foundation). Wiesbaden: Deutscher Universitätsverlag.

Schlink, G. (2006): The Diffusion of Creative Ideas: Why Does Geographical Proximity Matter? Paper presented at the Proximity Economics Congress, Bordeaux (URL: http://beagle.ubordeaux4.fr/conf2006/viewpaper.php?id=142, date accessed January 16, 2007).

Schuldt, N. and Bathelt, H. (2008): Practices of Global Buzz. Paper presented at the Annual Meeting of the Association of American Geographers, Boston.

Sharland, A. and Balogh, P. (1996): The value of nonselling activities at international trade shows. Industrial Marketing Management 25: 59-66.

Skov, L. (2006): The role of trade fairs in the global fashion business. Current Sociology 54: 764783.

Storper, M. and Venables, A. J. (2004): Buzz: face-to-face contact and the urban economy. Journal of Economic Geography 4: 351-370.

Strothmann, K.-H. (1992): Segmentorientierte Messepolitik (Segmented trade fair policy). In: Strothmann, K.-H. and Busche, M. (Eds.): Handbuch Messemarketing (Handbook of Trade Fair Marketing). Wiesbaden: Gabler, pp. 99-115.

Thrift, N. (2000): Performing cultures in the new economy. Annals of the Association of American Geographers 90: 674-692.

Torre, A. and Rallet, A. (2005): Proximity and localization. Regional Studies 39: 47-59.

Uzzi, B. (1996): The sources and consequences of embeddedness for the economic performance of organizations: the network effect. American Sociological Review 61: 674-698.

Uzzi, B. (1997): Social structure and competition in interfirm networks: the paradox of embeddedness. Administrative Science Quarterly 42: 35-67.

von Hippel, E. (2001): Innovation by user communities: learning from open-source software. MIT Sloan Management Review 42 (2): 82-86. 
Walther, J. B., Loh, T. and Granka, L. (2005): Let me count the ways: the interchange of verbal and nonverbal cues in computer-mediated and face-to-face affinity. Journal of Language and Social Psychology 24 (1): 36-65.

Watzlawick, P., Beavin, J. H. and Jackson, D. D. (2000): Menschliche Kommunikation - Formen, Störungen, Paradoxien (Human Communication - Forms, Interferences, Contradictions). 10th edition, Bern: Huber.

Wenger, E. (1998): Communities of Practice: Learning, Meaning, and Identity. Cambridge: Cambridge University Press.

Wickham, J. and Vecchi, A. (2008): Local firms and global reach: business air travel and the Irish software cluster. European Planning Studies 16: 693-710.

Zhao, S. (2003): Toward a taxonomy of copresence. Presence 12: 445-455. 
Table 1. Components of global and virtual buzz

\begin{tabular}{|c|c|c|}
\hline Components & Global buzz during international trade fairs & Virtual buzz during Internet trade fairs \\
\hline Global co-presence & $\begin{array}{l}\text { + High concentration of agents from all over the world } \\
\text { + Unique professional milieu } \\
\text { + Agents share dedication, patience and openness } \\
\text { + Few interruptions through daily routines } \\
\text { + Critical self-reflection } \\
\pm \text { High accessibility of exhibitors }\end{array}$ & $\begin{array}{l}\text { I Universal presence (not co-presence) } \\
+ \text { Getting easy/quick initial impressions of products/firms } \\
+ \text { Accessible 365/24 } \\
\text { + High connectivity for agents in isolated locations } \\
\text { - Disperse/unknown group of agents from all over the world } \\
\text { - Virtual moves embedded in daily routines/interruptions } \\
\text { - Simultaneous presence is not the rule due to time-lags }\end{array}$ \\
\hline Face-to-face interaction & $\begin{array}{l}\text { + Facial expressions, gestures and mimics } \\
\text { + Transfers of complex messages and instant feedback } \\
\text { + Decentralised information flows } \\
\text { + Permanent evaluation and re-evaluation of news } \\
\text { + Reduced risks in building future partnerships }\end{array}$ & $\begin{array}{l}\text { + In existing partnerships: focused meetings/quick information } \\
\text { transfer } \\
\text { - Eye-contact dilemma/lack of face-to-face interaction } \\
\text { - Hidden identities/intentions/agendas } \\
\text { - Sensitive areas are not discussed due to low data security } \\
\text { - Minimal sensible relations }\end{array}$ \\
\hline Observation & $\begin{array}{l}\text { + In-situ observation: inspection/“touch and feel” } \\
\text { + Observation of the reactions of others } \\
\text { + Visualisation of philosophy/behaviour of competitors } \\
\pm \text { Being accessible and subject to one another }\end{array}$ & $\begin{array}{l}\text { + Observation of web-sites and web-activities } \\
\text { - Designs/products can only be imagined, not experienced } \\
\text { - Evaluation/interpretation as an isolated process }\end{array}$ \\
\hline Focused communities & $\begin{array}{l}\text { + Diverse mixture of communities of practice/epistemic } \\
\text { communities } \\
+ \text { Overlapping/complementary knowledge bases } \\
+ \text { High-quality professional milieu } \\
+ \text { Collective interpretations ease individual choices } \\
\text { - Closed communities still exist }\end{array}$ & $\begin{array}{l}\text { + Random encounters with firms from related/unrelated sectors } \\
\text { - Rarely there is a critical mass of agents at a global scale, at } \\
\text { any point in time } \\
\text { - Access for newcomers is harder }\end{array}$ \\
\hline $\begin{array}{l}\text { Multiplex meetings and } \\
\text { relationships }\end{array}$ & $\begin{array}{l} \pm \text { Variety of planned/unplanned meetings with specialists } \\
+ \text { Tight network of different agents/relationships } \\
\text { + Direct/credible feedback mechanisms } \\
\text { + Development of initial trust based on swift trust } \\
+ \text { Multiple channels derive from face-to-face contact } \\
\text { - Coordination dilemma: depending on time schedule/position } \\
\text { within the hierarchy }\end{array}$ & $\begin{array}{l} \pm \text { Strong goal orientation } \\
\pm \text { Communication between two agents often limited } \\
\text { - Relevant agents/firms can easily be overlooked } \\
\text { - No direct feedback-mechanism/difficulty to filter information }\end{array}$ \\
\hline
\end{tabular}

Remark: “+” refers to an advantage, “-” to a disadvantage for the participating agents. 